\title{
Kościoły ewangelikalne w strefie konfliktu na wschodzie Ukrainy w latach 2014-2019
}

\section{Evangelical churches in the conflict zone in Eastern Ukraine in the years 2014-2019}

\section{Abstract}

Polish scientific publications regarding the conflict in Eastern Ukraine rarely describe the situation of religious minorities in the Donetsk and Luhansk People's Republics. They are more focused on its political, economic and military aspects. The author decided to verify the hypothesis that the conflict in eastern Ukraine has only political background, not religious, and, therefore, he has formulated the two research questions. First: what forms did the persecutions of Evangelical Christians take, and how did it affect the activities of these Christians? Second: what were the reasons for the persecutions of the Evangelical Christians? The text consists of three parts and conclusions. The first part provides general information about Evangelical Christians in Eastern Ukraine. The cases of persecution of this group between 2014 and 2019 are further described. The third part examines the factors determining the position of evangelical Christians in the Donetsk People's Republic and the Luhansk People's Republic. The last part of the article contains conclusions. The deliberations were prepared on the basis of carefully verified materials in English, Ukrainian and Polish. Many publications were downloaded from the websites of various international organizations, think tanks and research institutions. The author used a qualitative approach and referred to the sociological analysis of the conflict, taking into account political and religious studies.

Keywords: Evangelical Christians, persecution, Donetsk, Luhansk 


\section{Евангельские церкви в зоне конфликта на востоке Украины B 2014-2019 rr.}

\section{Аннотация}

Польские научные публикации о конфликте на востоке Украины редко описывают положение религиозных меньшинств в так называемых Донецкой и Луганской Народных Республиках. Они уделяют больше внимания политическим, экономическим и военным аспектам конфликта. Автор решил проверить гипотезу о том, что конфликт на востоке Украины является политическим, а не религиозным, и поэтому сформулировал два исследовательских вопроса. Первый звучит: какие формы приобрело преследование христиан веры евангельской и в какой степени оно повлияло на их деятельность? Второй вопрос: каковы были причины преследований христиан веры евангельской?

Предлагаемый текст состоит из трех частей и выводов. В первой части представлена общая характеристика христиан веры евангельской востока Украины. Далее описаны случаи преследования этой религиозной группы в 2014-2019 гг. В третьей части исследуются факторы, определяющие положение христиан веры евангельской в Донецкой Народной Республике и Луганской Народной Республике. Последний фрагмент статьи содержит выводы. Размышления подготовлены на основе тщательно проверенных материалов на английском, украинском и польском языках. Многие использованные публикации можно найти на сайтах международных организаций, аналитических центров и научных учреждений. Автор применил для анализа качественный подход, обращаясь и к социологическому анализу конфликта, с учетом политических и религиозных исследований.

Ключевые слова: евангельские христиане, гонения, Донецк, Луганск

\section{Wstęp}

W starciach na wschodzie Ukrainy, które rozgrywały się w latach 20142019, wśród przyczyn, a także czynników warunkujących, obecne były elementy konfliktu odnoszące się do tożsamości religijnej, wyrażające się w co najmniej trzech dziedzinach. Po pierwsze, w toczącej się rywalizacji o wpływy pomiędzy Ukraińskim Kościołem Prawosławnym Patriarchatu Kijowskiego (UKPPK) oraz Ukraińskim Kościołem Prawosławnym Patriarchatu Moskiewskiego (UKPPM), który dla Kremla jest instrumentem oddziaływania na społeczeństwo Ukrainy. Po drugie, w inicjatywach podejmowanych na 
terenach, nad którymi Kijów utracił kontrolę, zmierzających do ograniczenia działalności wspólnot religijnych, postrzeganych przez Rosyjski Kościół Prawosławny (RKP) jako konkurencyjne. Po trzecie, w sympatiach lub antypatiach politycznych głównych związków wyznaniowych na Ukrainie (Zenderowski, 2014, s. 601-606).

Analizując doniesienia medialne oraz informacje zawarte w raportach organizacji międzynarodowych i pozarządowych, dostrzec można, że na wschodzie Ukrainy w latach 2014-2019 dochodziło do prześladowań religijnych. Dotykały one głównie: UKPPK, Ukraiński Kościół Greckokatolicki (UKG), chrześcijan ewangelikalnych, Świadków Jehowy, mormonów oraz wyznawców islamu. Działania te o charakterze systemowym utrudniały, a nawet całkowicie uniemożliwiały realizowanie wspólnotowych praktyk religijnych oraz podejmowanie innych aktywności, np. misyjnych czy socjalnych. W niektórych wypadkach przyjmowały postać uprowadzeń, pobić, bezprawnego przetrzymywania, tortur, zabójstw, grabieży lub niszczenia mienia należącego do organizacji religijnych (CCL, 2015, s. 4; USCIRF, 2019, s. 80; OSCE, 2016, s. 20). Kościoły ewangelikalne (KE) najczęściej mierzyły się z zarzutami: powiązań finansowych z CIA, prowadzenia pro-ukraińskich działań propagandowych, negatywnego oddziaływania na wyznawców prawosławia, a nawet podważania ładu państwowego.

W polskiej literaturze naukowej sprawa konfliktu na wschodzie Ukrainy podejmowana jest w pracach zwartych i publikacjach rozproszonych. Dominują w nich treści dotyczące analizy: geopolitycznych determinantów starć, ujmowanych w kontekście rywalizacji USA, Rosji i Chin, podłoży konfliktu ukraińsko-rosyjskiego, istoty rosyjskich działań militarnych i pozamilitarnych, prowadzonych wobec Kijowa, czy implikacji konfliktu dla polityki zagranicznej i bezpieczeństwa RP (Surdyk 2017; Baluk, Doroszko, 2017; Pacek, 2018; Banasik, 2016; Pawlak, 2017; Rogozińska, 2019). Sprawy odnoszące się do religijnych kontekstów tych wydarzeń podejmowane są w ograniczonym zakresie.

Niedostatek opracowań poświęconych tej właśnie problematyce stał się główną przesłanką do przyjrzenia się sytuacji KE na wschodzie Ukrainy ${ }^{1}$.

${ }^{1}$ Ewangelikalizm to: ,ruch protestancki, akcentujący historyczne prawdy wiary określone przez starożytne sobory ekumeniczne i XVI-wiecznych reformatorów. Teologiczna treść 
Wstępna analiza materiału badawczego zaowocowała przyjęciem hipotezy roboczej: konflikt co do swej natury nie ma podłoża religijnego, natomiast kwestie religijne są zinstrumentalizowane do celów politycznych. W jej następstwie sformułowano dwa pytania badawcze. Pierwsze: jakie formy przyjmowały prześladowania KE i w jakim stopniu wpłynęły na ich działalność? Drugie: jakie były przesłanki prześladowań KE?

Autor, realizując powyższe zamierzenia badawcze, posłużył się ujęciem jakościowym. Praca, będąca opracowaniem z zakresu bezpieczeństwa społecznego, odwołuje się do analizy socjologicznej konfliktu, z uwzględnieniem aspektów politologicznych i religioznawczych. W tekście poddano oglądowi materiały pierwotne i wtórne w językach angielskim, ukraińskim i polskim. Podczas ich selekcji dołożono starań, aby wyeliminować źródła zawierające znamiona materiałów o charakterze propagandowym. Tekst o układzie problemowym otwiera wstęp, a kolejny fragment wprowadza czytelnika w problematykę artykułu. Dalej przybliżono przypadki represyjnych działań wobec KE oraz poddano analizie ich przyczyny. Całość artykułu zamykają wnioski.

\section{Kościoły ewangelikalne na wschodzie Ukrainy}

Przed wybuchem konfliktu, w Obwodzie Donieckim działało 1797 organizacji religijnych, z czego 552 stanowiły KE. W Obwodzie Ługańskim liczbę wszystkich wspólnot religijnych szacowano na 835, a w tym $230 \mathrm{KE}$.

W następstwie utraty kontroli nad tymi obszarami przez Kijów, pogorszeniu zaczęła ulegać sytuacja egzystujących tam wspólnot religijnych, za wyjątkiem tych, które identyfikują się z RKP. Nowe rozwiązania prawne przyjęte przez separatystów nałożyły na wszystkie związki wyznaniowe obowiązek ponownej rejestracji. Ponadto, ograniczeniu uległa ich możliwość publicznego sprawowania kultu, spotkań w prywatnych mieszkaniach, wytwarzania i dystrybucji literatury, czy też rozpowszechniania przekonań za pośrednictwem środków masowego przekazu. Począwszy od 2014 r., KE

tego przesłania podkreśla najwyższą rangę Biblii jako ostatecznego autorytetu w sprawach wiary i praktyki chrześcijańskiej, centralne znaczenie Chrystusowego zbawczego dzieła dokonanego na krzyżu, nieodzowną konieczność osobistego przyswojenia przez wierzącego owoców zbawczego czynu Jezusa" (Zieliński, 1995, s. 240). 
Tabela 1. Organizacje religijne Obwodów Donieckiego i Ługańskiego przed rosyjską okupacją $2014 \mathrm{r}$.

\begin{tabular}{|l|c|c|}
\hline \multicolumn{1}{|c|}{ Typ wspólnoty religijnej } & $\begin{array}{c}\text { Obwód } \\
\text { Doniecki }\end{array}$ & $\begin{array}{c}\text { Obwód } \\
\text { Lugański }\end{array}$ \\
\hline Ukraiński Kościół Prawosławny Patriarchatu Moskiewskiego & 762 & 423 \\
\hline Kościoły ewangelikalne (baptyści, zielonoświątkowcy) & 552 & $230^{*}$ \\
\hline Ukraiński Kościół Prawosławny Patriarchatu Kijowskiego & 86 & 35 \\
\hline Świadkowie Jehowy & 83 & 28 \\
\hline Kościół Adwentystów Dnia Siódmego & 49 & 39 \\
\hline Wspólnoty muzułmańskie & 38 & 13 \\
\hline Ukraiński Kościół Greckokatolicki & 36 & 6 \\
\hline Wspólnoty judaistyczne & 19 & 14 \\
\hline Wspólnoty buddyjskie & 14 & 6 \\
\hline Kościół katolicki & 14 & - \\
\hline Wspólnoty ruchu Hare Krishna & 8 & - \\
\hline Pozostałe & 136 & 44 \\
\hline
\end{tabular}

* Kościoły ewangelikalne działające na wschodzie Ukrainy nie udostępniają danych dotyczących liczebności swoich zborów. Z dużą dozą prawdopodobieństwa można przyjąć, że wiele $\mathrm{z}$ tych parafii to małe wspólnoty (szerzej na temat metod prowadzenia badań przynależności wyznaniowej i kościelnej mieszkańców Ukrainy w: Конфесійна та церковна належність громадян Украӥни (січень 2020 р. сочіологія) „CR, 2020«). Podobnie sytuacja wygląda w Polsce. Jako przykład można przywołać Kościół Zielonoświątkowy w RP, który jest najliczniejszą rodzimą wspólnotą ewangelikalną. W 2018 r. liczyła ona 25 tys. wiernych, skupionych w 254 parafiach (GUS, 2019, s. 145). Podkreślmy, że największa grupa zborów Kościoła zielonoświątkowego otacza opieką do 100 wiernych.

Źródło: opracowano na podstawie Zoria, 2018.

zaczęły doświadczać konfiskat mienia, w tym również sal modlitw, bezprawnego aresztowania i przetrzymywania osób duchownych i świeckich, czy nakładania dotkliwych kar finansowych na duszpasterzy oraz wiernych. W maju 2015 r. w Doniecku Aleksandr Zacharczeno zadeklarował, że władze postanowiły uznać tylko cztery wyznania: prawosławie, rzymski katolicyzm, islam i judaizm. Pozostałe sklasyfikowano jako sekty. Podobnie postąpiło Ministerstwo Bezpieczeństwa Publicznego ŁRL, które od grudnia 2016 r. podjęło zdecydowane działania, mające na celu ograniczenie działalności „nietradycyjnych organizacji religijnych”, które również określone zostały mianem „sekt”. Restrykcje te kontynuowane były w kolejnych latach (MBPDRL, 2015). 
Protestanci są jedną z mniejszych grup wyznaniowych działających na obszarze Ukrainy. W 2018 r. jej liczebność szacowano na 2,2\% całej populacji zamieszkującej to państwo. Ich religijność - pisał Dmytro Vovk - ,jest prawie zawsze zinstytucjonalizowana: są zarejestrowani jako członkowie swojej wspólnoty, są finansowo i organizacyjnie zaangażowani w jej życie i regularnie uczęszczają na spotkania kościelne. Dlatego niewielka mniejszość protestancka stanowi istotną, aktywną społecznie część religijnego pejzażu Ukrainy" (Vovk, 2020). Na wschodzie Ukrainy znajdują się liczne skupiska wiernych tego nurtu tradycji chrześcijańskiej, a pierwsze wspólnoty ewangelikalne pojawily się tam na początku XX wieku. W latach 2000-2018 liczba protestantów w tym regionie oscylowała w przedziale od 0,9 do 3,2\% ogółu jego mieszkańców.

Tabela 2. Protestanci na wschodzie Ukrainy w latach 2000-2018 [\%] w skali ogółu populacji regionu

\begin{tabular}{|l|c|c|c|c|c|c|c|}
\hline \multirow{2}{*}{\multicolumn{1}{c|}{ Obszar }} & \multicolumn{7}{|c|}{ Rok } \\
\cline { 2 - 8 } & $\mathbf{2 0 0 0}$ & $\mathbf{2 0 1 0}$ & $\mathbf{2 0 1 3}$ & $\mathbf{2 0 1 4}$ & $\mathbf{2 0 1 6}$ & $\mathbf{2 0 1 7}$ & $\mathbf{2 0 1 8}$ \\
\hline Wschód Ukrainy & 1,9 & 3,2 & 1,2 & 0,9 & 2,2 & 1,1 & 1,7 \\
\hline
\end{tabular}

Źródło: opracowano na podstawie CR, 2018, s. 7-13.

Powyższy stan rzeczy warunkowany był w dużej mierze przesłankami o charakterze ekonomicznym. We wschodniej, zurbanizowanej części Ukrainy, w latach 90. znacznie mocniej odczuwano kryzys gospodarczy, niż w pozostałych regionach kraju. Ta sytuacja wpłynęła na większą otwartość lokalnej społeczności na zmiany o charakterze duchowym. Nie była jednak trwałą tendencją, gdyż wraz ze wzrostem stopy życiowej zainteresowanie KE zaczynało maleć.

Zdaniem Ekateriny Shapoval, protestanci żyjący w DRL i ŁRL, są jednym z najbardziej patriotycznych środowisk społecznych, które wspiera ukraińską armię, ale także wysoce prześladowaną mniejszością religijną. Według szacunków, w tym nurcie około 20 tys. osób czynnie działa na rzecz integralności terytorialnej Ukrainy. Ich opowiedzenie się po stronie Kijowa wynikało nie tylko z przemocy, której doświadczyli ze strony prorosyjskich bojowników, ale także dostrzeżenia występowania wśród miejscowej ludności 
resentymentu za czasami Związku Radzieckiego, w których nie było jednak miejsca na prawdziwą wolność wyznania (Шаповал, 2016).

\section{Prześladowania chrześcijan ewangelikalnych w DRL i ŁRL}

W maju i czerwcu 2014 r. na wschodzie Ukrainy dochodziło do aktów przemocy wobec wiernych KE, w tym również osób duchownych. Najczęściej przyjmowały one postać uprowadzeń, grabieży i pobić. Takie zdarzenia odnotowano m.in. w Słowiańsku, Gorłówce, Doniecku oraz Drużkowce (PE, 2014). Grupy zbrojne DRL i ŁRL zakłócały przebieg zgromadzeń religijnych, przejmowały domy modlitwy, które następnie wykorzystywano jako: punkty do prowadzenia ostrzału wojsk ukraińskich, koszary, szpitale, sale gimnastyczne lub magazyny broni (Donieck, Gorłówka, Słowańsk, Szahtarsk, Drużkowka, Czystaiakowo). KE musiały również mierzyć się z rosyjską ofensywą propagandową, której celem było ich zdyskredytowanie w oczach opinii publicznej oraz nadanie religijnego kontekstu konfliktowi w DRL i ŁRL. W działaniach tych uczestniczył także RKP. Nadmieńmy, że w sierpniu 2014 r. metropolita Cyryl, w piśmie skierowanym do Patriarchy Ekumenicznego Konstantynopola, Bartłomieja I, określił walki w Donbasie mianem wojny religijnej. Zarzucił KE oraz UKG propagowanie nienawiści wobec wyznawców prawosławia, prowadzenie działań, które mają na celu wyeliminowanie ich wspólnot z całego obszaru Ukrainy. Utrzymywał także, iż w czasie starć bojownicy, wywodzący się z KE oraz UKG zbrojnie wystąpili przeciwko duchowieństwu prawosławnemu (CCL/IPHR, 2015, s. 5-7).

16 maja 2014 r. w Słowiańsku prorosyjscy bojownicy schwytali i przez siedem godzin przetrzymywali w budynku służby bezpieczeństwa biskupa Ukraińskiego Kościoła Bożego - Aleksieja Demidowicza. Próby jego uwolnienia podjął się Sergiej Kosiak - pastor parafii należącej do Wspólnoty Zborów Bożych². W tym celu udał się do siedziby Donieckiej Obwodowej Administracji Państwowej, gdzie został dotkliwie pobity przez rebeliantów.

${ }^{2}$ Edward Czajko, odnosząc się do określenia „zbór”, pisał: „Protestantyzm znalazł lepszy polski odpowiednik dla greckiego wyrazu ekklesia niż »kościół« (warownia, kasztel, twierdza). Tym lepszym odpowiednikiem jest wyraz »zbór « , stosowany do dzisiaj, przynajmniej w odniesieniu do lokalnej wspólnoty wierzących w Chrystusa” (Czajko, 2014, s. 179). 
Zwolniono go dopiero po ośmiu godzinach. W następstwie odniesionych obrażeń Kosiak potrzebował pomocy medycznej (IRF, 2014).

W początkowej fazie konfliktu najtragiczniejszym przypadkiem prześladowań religijnych były wydarzenia, które rozegrały się ósmego czerwca 2014 r., w Słowiańsku. W mieście operował wówczas przybyły z Krymu oddział Rosyjskiej Armii Prawosławnej, dowodzony przez Igora Girkina (ps. Igor Striełkow) - byłego oficera Specnazu GRU. Jego bojownicy uprowadzili braci Alberta i Rubena Pavenko - synów Aleksandra Pavenko - pierwszego pastora zboru Przemienienia Pańskiego Kościoła Chrześcijan Wiary Ewangelicznej Ukrainy, a także dwóch diakonów - Wiktora Bradarskiego i Władimira Wieliczko. Pretekstem do ich aresztowania był donos, zawierający zarzuty dostarczania żywności Gwardii Narodowej Ukrainy oraz ukraińskim wojskom, stacjonującym w punktach kontrolnych wokół miasta, a także informowania tych formacji o działaniach rebeliantów.

Pojmanych przetrzymywano w piwnicy budynku straży pożarnej, gdzie byli torturowani (Karpitsky, 2015, s. 13). Nazajutrz zostali zamordowani, przy czym w mediach pojawiały się różne wersje tego dramatu. Część utrzymywała, że zatrzymani zostali zabici w miejscu, w którym byli przetrzymywani (Васин, 2014a).W pozostałych publikacjach obecna była sugestia, że pozbawiono ich życia poza miastem, przy drodze prowadzącej w kierunku góry Karaczun (Фионик, 2014). Sprawcy tej tragedii, zacierając ślady zbrodni, upozorowali ostrzelanie przez ukraińskie wojsko samochodu Bradarskiego, w którym znajdowali się również bracia Pavenko oraz Wieliczko. Nie sposób jednak jednoznacznie rozstrzygnąć, czy przed tym atakiem jeszcze żyli, czy też w pojeździe były już ich zwłoki.

Ciał zabitych nie wydano rodzinie, lecz pochowano je w zbiorowej mogile na terenie szpitala dziecięcego w Słowiańsku, wraz ze zwłokami separatystów poległych w czasie walk. Ich identyfikacji dokonano dopiero po wyjściu bojowników z miasta i ekshumacji ciał. Wtedy też wstępnie ustalono personalia oprawców ofiar. W tej sprawie - dodajmy - pojawił się również wątek rabunkowy, gdyż trzech uprowadzonych posiadało wartościowe samochody, które zostały im odebrane przez rebeliantów. Pojazd Brodskiego był najstarszy, dlatego - zdaniem ukraińskich śledczych - w tym właśnie samochodzie umieszczono pojmanych (Peterson, 2014). Pewne światło na motywy działania oprawców rzuca wywiad Gordona J. Adamsa z pastorem 
Pavenko. Duchowny stwierdził, że w 2015 r. z anonimowego, moskiewskiego numeru telefonu otrzymał propozycję podania personaliów zbójców jego synów, w zamian za wysoką opłatę. Pastor odmówił, a następnie zapytał rozmówcę o motywy zbrodni. Usłyszał, że jej celem było zastraszenie i zdestabilizowanie całej wspólnoty (Adams, 2017). Dochodzenie w tej sprawie wykazało, iż mordu dokonali Anton Czernyszow i Jewgienij Puszkow ze Słowiańska, a także pochodzący z Makijewki Oleg Obraztsow (RISU, 2018a).

14 czerwca, w następstwie zamachu samobójczego bojownika DRL, dokonanego na moście w Mariupolu, zabity został pastor Siergiej Skorobaha z Kościoła Odrodzenia - przewodniczący miejskiej Rady Kościołów. Odpowiedzią na te i inne wydarzenia było oświadczenie Rady Ewangelicznych Kościołów Protestanckich na Ukrainie (lipiec, 2014). Potępiono w nim wszelkie przejawy dyskryminacji i prześladowań o podłożu religijnym. Ponadto, wskazano, że nietolerancja religijna i wrogość nie są nieodłącznymi cechami ukraińskiego społeczeństwa (Havryliuk, et. al., 2014). Ta konstatacja obecna jest również w raporcie wydanym w 2018 r. przez Instytut Wolności Religijnej (Kijów). Jego autorzy wskazywali przy tym, iż Moskwa wykorzystuje czynnik religijny jako jedno z hybrydowych narzędzi wojennych, ,w których kluczową rolę przypisuje się "podstępnej propagandzie i destabilizacji społeczeństwa motywowanej różnicami religijnymi, etnicznymi i językowymi«" (IRF, 2018, s. 20).

21 czerwca separatyści zajęli budynek wspólnoty „Słowo Życia” w Szachtarsku, a także porwali jej proboszcza Mykołę Kaliniczenko, którego po okradzeniu z samochodu osobowego wypuszczono. Pięć dni później podobny los spotkał pastora Kościoła Zwycięstwa w Drużkiwce - Pawła Lesko oraz jego żonę. Małżeństwo zostało aresztowane, a bojownicy przetrzymywali ich w niewoli przez tydzień (Васин, 2015). Na początku sierpnia porwany został pastor Aleksander Chomczenko, który w Doniecku na placu Konstytucji współorganizował „duchowy Majdan” - ponaddenominacyjny maraton modlitewny w intencjach ochrony miasta, bezpieczeństwa jego mieszkańców oraz jedności i integralności Ukrainy. Po przewiezieniu do Maciejewki postawiono mu zarzuty współdziałania z ukraińskim wojskiem oraz prowadzenia działalności sekciarskiej. Przez dziewięć dni Chomczenko był brutalnie bity, duszony, trzykrotnie symulowano jego rozstrzelanie. Uwolniono pastora dopiero w następstwie międzynarodowej interwencji, po 
tym, jak upublicznione zostały wiadomości o jego sytuacji. Obrażania, które wówczas odniósł, doprowadziły do jego przedwczesnej śmierci w marcu 2018 r. (CCL/IPHR, 2015).

14 października separatyści aresztowali pod pretekstem współpracy z ukraińskim wojskiem asystenta pastora Kościoła Dobrej Nowiny Siergieja Sajekowa i jego 14-letniego syna Danyła, z miasta Krasnodon. Po czterech dniach brutalnych przesłuchań zatrzymani zostali zwolnieni. Sajekow wraz $\mathrm{z}$ całą rodziną został zmuszony do przesiedlenia się na zachodnią Ukrainę (Васин, 2015).

W kolejnych latach w DRL oraz ŁRL nadal trwały represje wobec KE, przy czym nie przyjmowały tak drastycznych form, jak w 2014 r. I tak, np. pod koniec sierpnia 2017 r. bojownicy DRL uniemożliwili powrót do domu Aleksandrowi Nagirniakowi - pastorowi wspólnoty baptystycznej w Janakijewie, który wcześniej przebywał u syna w Mariupolu. W konsekwencji, parafia nie tylko straciła duszpasterza, ale także rozdzielono rodzinę duchownego, gdyż jego żona wraz z małymi dziećmi pozostawała w miejscu zamieszkania (RISU, 2017). 27 marca 2018 r. bojownicy ŁRL dokonali rabunku w parafii baptystycznej w Kadijewce. Salę modlitwy ogołocono ze wszystkiego, co posiadało jakąś wartość (RISU, 2018b). W czerwcu w Makijewce rebelianci zamknęli jeden zbór zielonoświątkowy, a miesiąc później dom modlitwy baptystów (Zoria, 2018). Na początku sierpnia uzbrojeni separatyści wtargnęli w Doniecku do Kościoła Łaski, zarekwirowali komputer należący do wspólnoty, a także przez kilka godzin przetrzymywali pastora Wiktora Kowala oraz jego współpracowników (GPCh, 2018). Podobne wydarzenia miały miejsce w ewengelikalnym zborze w Ałczewsku. We wrześniu zamknięta i zaplombowana został sala modlitwy baptystów w Nowoazowsku (Corley, 2018). Pod koniec tego samego miesiąca bojownicy ŁRL wtargnęli także do baptystycznego zboru w Briance, zakłócając tym samym nabożeństwo (RISU, 2018c).

Wiosną 2019 r. w ŁRL i DRL nadal dochodziło do represji wobec ewangelikalnych protestantów. W ŁRL „władze nakazały kościołom zrzeszonym w Unii Baptystycznej, by zaprzestały, pod groźbą kary, organizowania publicznych nabożeństw" (GPCh, 2019). Dodajmy, że w 2019 r. w ŁRL proces ponownej rejestracji przeszło 195 organizacji religijnych, $w$ tej grupie nie było żadnego Kościoła protestanckiego. Dane osobowe, które KE musiały 
ujawnić w trakcie procedury legalizacyjnej, przekazane zostały służbom bezpieczeństwa. Te z kolei okresowo powtarzają naloty na miejsca zgromadzeń związków wyznaniowych, które nie uzyskały rejestracji. Szczególnie monitorowani są ich duszpasterze, których inwigilacja prowadzona jest w miejscach zamieszkania oraz w pracy. Z kolei w DRL 90\% organizacji religijnych, które złożyły wniosek o rejestrację, pozytywnie przeszło tę procedurę w 2019 r. Przy czym, także i w tym regionie służby bezpieczeństwa stale obserwują i wywierają presję na nieortodoksyjne wspólnoty (Булатчик, 2019).

\section{Czynniki determinujące położenie Kościołów ewangelikalnych w DRL i ŁRL}

Sytuacja ewangelikalnych protestantów w DRL i ŁRL warunkowana jest splotem wielorakich czynników. Analizując położenie prawne tych wspólnot należy wskazać co najmniej na dwa rodzaje dokumentów. Są to przyjęte w republikach konstytucje, a także ustawy o wolności wyznania i związkach wyznaniowych (RDRL, 2014; RDRL, 2019; RŁRL, 2014; RŁRL, 2018). W obowiązujących obecnie ustawach zasadniczych znajdziemy paralelne zapisy dotyczące: rozdziału państwa od organizacji religijnych, równości wyznań wobec prawa, a także odrzucenia możliwości nadania jakiemuś wyznaniu statusu religii państwowej. Ponadto, dokumenty te deklarują, że każdy ma zagwarantowaną wolność sumienia i wyznania oraz praktykowania religii. Ujęcia te nie odbiegają zatem od praktyki legislacyjnej wielu innych państw. Nadmieńmy jednak, że w pierwszej wersji konstytucji DRL znajdowały się ustępy faworyzujące RKP (Васин, 2014b). Z kolei, wczytując się w teksty ustaw o wolności wyznania i związkach wyznaniowych zauważymy, że w ich preambułach zawarto deklaracje świeckości państwa, ale także zapisy o szczególnej roli prawosławia w historii oraz w dziele kształtowania duchowości, moralności i kultury tych regionów. Co więcej, we wstępach obecny jest katalog religii, które stanowią integralną część dziedzictwa mieszkańców DRL i ŁRL (chrześcijaństwo, islam, judaizm i inne), jak również deklaracje przeciwdziałania nienawiści i wrogości o podłożu religijnym. Podkreślmy, że zapisy te odwzorowują niemal literalnie preambułę rosyjskiej ustawy o wolności sumienia i związkach wyznaniowych. 
Tych podobieństw jest więcej. Świadczą o tym chociażby zapisy dotyczące ścigania, zgodnie z obowiązującym prawem, destrukcyjnych grup religijnych, zawarte we wszystkich trzech dokumentach. Są one również konsekwencją przyjętych wcześniej ustaw o przeciwdziałaniu działalności ekstremistycznej. Zdaniem Konstatnitna Skorkina, powyższe regulacje otwierają drogę do represjonowania grup religijnych, które prowadzą działalność misyjną i są oskarżane przez RKP o uprawianie prozelityzmu. Dodajmy, że dla KE dużą niedogodnością są również procedury rejestracyjne, zawarte w ustawach wyznaniowych, bez poddania się którym nie jest możliwe prowadzenie dalszej działalności religijnej. Pastor Kosiak, odnosząc się do tej sprawy, sygnalizował, że w komisjach, podejmujących decyzję o rejestracji bądź jej odmowie, zasiadają kapłani RKP, rozstrzygający w rzeczywistości, który kościół może działać na „ich terytorium kanonicznym” (Булатчик, 2019).

Analizując przesłanki religijne, wpływające na położenie KE w DRL i ŁRL, konieczne jest wskazanie na charakterystyczne dla eklezjologii RKP pojęcie terenu kanonicznego. Rozumiany jest on jako obszar podlegający wyłącznemu zwierzchnictwu tej wspólnoty. Przy czym, od tego określenia niezbędne jest odróżnienie wyrażenia językowego „terytorium kanoniczne”, „pod którym należy rozumieć nie tylko aktualną przynależność jurysdykcyjną danego obszaru, lecz także odniesienia historyczne, a więc to czy w przeszłości jakieś ziemie nie przynależały do Rosyjskiej Cerkwi Prawosławnej" (Sobczak, 2018, s. 9). RKP utrzymuje, że jego teren kanoniczny obejmuje obszary: Federacji Rosyjskiej, Ukrainy, Białorusi, Litwy, Łotwy, Estonii, Mołdawii, Azerbejdżanu, Kazachstanu, Kirgistanu, Tadżykistanu, Turkmenistanu i Uzbekistanu. RKP wyklucza zatem możliwość prowadzenia działalności misyjnej w tej przestrzeni przez inne wspólnoty religijne, a także tworzenia ich struktur organizacyjnych, np. kolejnych, autokefalicznych Cerkwi. Odnosząc się do tej praktyki, ks. Marek Ławreszuk podkreśla, że dla RKP idea „terenu kanonicznego" stała się instrumentem, którym narusza się niezależność lokalnych Kościołów, czyli narzędziem realizacji „eklezjalnego imperializmu”., Fundamentem współczesnej zasady „terenu kanonicznego” dodaje - staje się tendencja do organizacji życia eklezjalnego na fundamencie etnicznym. W duchu soborowości i jedności Kościoła zjawisko to nie powinno mieć miejsca" (Ławreszuk, 2009, s. 99). 
Dezaprobata Cerkwi Moskiewskiej wobec innych poczynań misyjnych na tym obszarze jest również następstwem odrzucenia tezy, że człowiek może osiągnąć zbawienie poza „granicami prawosławia”, czyli m.in. w pozostałych wyznaniach chrześcijańskich (Kałużny, 2014, s. 82). Tymczasem, ewangelikalni protestanci charakteryzują się znaczną aktywnością misyjną, a krzewienie Ewangelii ujmują jako „święty obowiązek”. Co więcej, ewangelikalizm, afirmując model indywidualnej pobożności, „,kładzie nacisk na nawrócenie i nowonarodzenie, które sprawiają, że człowiek staje się chrześcijaninem. Nie przynależność instytucjonalna, ale pełne zawierzenie Chrystusowi otwiera człowiekowi drogę zbawienia" (Szczerba, 2013, s. 20).

Powyższe przesłanki sprawiają, że w polu zainteresowania KE w DRL i ŁRL, znalazły się nie tylko osoby areligijne, ale także wyznawcy różnych religii, a w tym innych odłamów chrześcijaństwa. W konsekwencji, praca misyjna jest prowadzona również wśród osób, które zostały ochrzczone w obrządku RKP. Z tego powodu jego patriarchat głoszenie Ewangelii przez KE postrzega jako formę prozelityzmu.

W tym kontekście rozważań wskazane jest również zwrócenie uwagi na pojęcie „Russkij Mir” (Rosyjski Świat), pojawiające się w wystąpieniach przedstawicieli RKP, ale także Kremla ${ }^{3}$. Najczęściej bywa ujmowane jako: „skupiona wokół Rosji wspólnota ludzi mówiących po rosyjsku, identyfikujących się z religią i kulturą prawosławną i odwołujących się do wspólnych wartości, bez względu na obywatelstwo i pochodzenie etniczne. Rdzeniem Rosyjskiego Świata jest zatem wspólnota rosyjsko-ukraińsko-białoruska, jego podstawowym obszarem: ludność rosyjskojęzyczna obszaru postradzieckiego, a w najszerszym rozumieniu: ludzie z całego świata spełniający wspomniane trzy kryteria" (Studenna-Skrukwa, 2014, s. 30). Przy czym, RKP ów terytorialny trzon określa mianem „Świętej Rusi” i łączy go z mesjańską ideą „Moskwy - Trzeciego Rzymu” (RKP, 2009). Odnosząc się do tej sprawy, sowietolog Alan Besançon zauważa: „Poczucie nierozerwalności rosyjskiego prawosławia jest wciąż żywe i głoszone bardziej intensywnie, niż kiedykolwiek po siedemdziesięciu latach komunizmu. Sołżenicyn nie dopuszcza możliwości, aby Rosjanin porzucił prawosławie na rzecz innej religii bez

\footnotetext{
${ }^{3}$ Rzeczywistym celem Fundacji jest przeciwstawienie się wpływom zachodnim w przestrzeni poradzieckiej.
} 
jednoznacznego wyrzeczenia się rosyjskości. Taka jest również dzisiaj pozycja patriarchy Cyryla, mocno popieranego przez Putina i państwo rosyjskie" (Besançon, 2015, s. 27). W praktyce Kreml i RKP ideę „Rosyjskiego Świata” wykorzystują do legitymizacji swojej ingerencji na obszarze postsowieckim, a zatem ograniczania wpływów m.in. instytucji religijnych, wywodzących się z zachodniego świata (Ławreszuk, 2009, s. 97).

KE działające w $Ł R L$ i DRL, podobnie jak inne zbiorowości tego nurtu pobożnościowego, określane są mianem „kościołów wyboru”, do których jednostki przyłączają się wyłącznie w następstwie własnej, wolnej decyzji. O członkostwie nie decyduje zatem fakt urodzenia się i / lub wychowania w tym środowisku (Modnicka, 2013, s. 42). Powyższa cecha koresponduje z tak charakterystycznymi dla społeczeństw demokratycznych wolnościami sumienia i wyznania, obejmującymi m.in. „wolność posiadania przekonań religijnych, przyjmowania i odrzucania religii według własnego wyboru" (Sobczak, Gołda-Sobczak, 2012, s. 28). RKP w odniesieniu do wolności sumienia zajmuje specyficzne stanowisko. Cerkiew zauważa, że umożliwia ona Kościołowi funkcjonowanie w świecie niereligijnym, gwarantując mu posiadanie statusu prawnego w państwie świeckim. Przy czym, jest również dowodem, na postępujący proces przesuwania religii ze sfery publicznej do prywatnej, świadczący o rozpadzie systemu wartości duchowych, czyli zaniku aspiracji do zbawienia większości społeczeństwa (RKP, 2008). Wśród wyznawców rosyjskiego prawosławia pojawiają się również głosy, że wolność sumienia może stanowić zagrożenie dla porządku publicznego. Ten punkt widzenia propaguje m.in. Aleksander Dvorkin - autor terminu ,sekta totalitarna" - reprezentujący radykalną gałąź prawosławnej apologetyki (Dvorkin, 2005, s. 99 i n.). Jego poglądy korespondują z przekonaniami nasilającymi się od początku nowego stulecia w rosyjskich kręgach rządowych oraz w RKP, o wywrotowym potencjale niezależnych grup religijnych, co Amerykańska Komisja ds. Wolności Religijnej, dosadnie określiła mianem „paranoi z czasów sowieckich" (USCIRF, 2018, s. 77).

Analizując zagadnienie stosunku RKP do KE, konieczne jest zasygnalizowanie jeszcze dwóch spraw. Po pierwsze, część wspólnot ewangelikalnych o amerykańskiej proweniencji, które w latach 90 . XX wieku prowadziły ożywioną działalność misyjną na obszarze postsowieckim, była aktywna nie tylko w krzewieniu Ewangelii, ale także w „agresywnej” polemice z innymi, 
zarówno starszymi, jak i nowymi ruchami religijnymi, co oczywiście nie umknęło uwadze RKP (Shterin, Richardson, 2002, s. 5 i n.). Nie dziwi zatem, że w ortodoksyjnej, internetowej encyklopedii $A B C$ wiary zamieszczono wskazówki, jak prowadzić rozmowy z protestanckimi misjonarzami (Максимов, 2015). Po drugie, część wiernych i liderów KE aktywnie popierała Euromajdan (EP, 2016). Przypomnijmy, że Ołeksandr Turczynow, pełniący liczne funkcje państwowe, jest świeckim kaznodzieją jednego ze zborów baptystycznych w Kijowie (Gowryś, 2014).

\section{Wnioski}

Przegląd zebranego materiału źródłowego w zdecydowanej mierze potwierdził zasadność przyjętej hipotezy roboczej, że konflikt co do swej natury nie ma podłoża religijnego, natomiast kwestie religijne są zinstrumentalizowane do celów politycznych. Charakter i skala represji, których doświadczyły wspólnoty ewengelikalne, zwłaszcza w początkowym okresie konfliktu, wskazują, że na wschodzie Ukrainy prowadzona była wojna hybrydowa. Kreml, realizując swoje geopolityczne cele, instrumentalnie wykorzystał m.in. rosyjskojęzycznych wyznawców prawosławia, identyfikujących się z Rosją i RKP, jak również charakteryzujących się resentymentem za czasami ZSRR. W działaniach tych posługiwano się nie tylko brutalną siłą, ale także dezinformacją, realizowaną, np. za pośrednictwem państwowej rozgłośni „Głos Rosji”. Nadmieńmy, że na tej antenie rozpowszechniano nieprawdziwe informacje dotyczące okoliczności zabójstwa czterech zielonoświątkowców ze Słowiańska, przypisując tę zbrodnię ukraińskim nacjonalistom (KHRPG, 2017).

Pomimo prób podejmowanych przez Rosję nadania wydarzeniom w ŁRL i DRL charakteru konfliktu o podłożu religijnym, narracja ta nie została przyjęta przez zachodnich komentatorów oraz instytucje zajmujące się monitorowaniem przestrzegania praw człowieka. W publikacjach powstałych w tych kręgach, Kreml postrzegany jest jako istotny uczestnik wydarzeń DRL i ŁRL, odpowiedzialny za falę prześladowań religijnych.

Marginalizowanie KE w DRL i ŁRL wpisuje się w kontekst działań Moskwy, służących realizacji projektu Rosyjskiego Świata, wspieranego przez RKP. Przy czym bliskie związki Cerkwi z władzami Federacji Rosyjskiej przynoszą Patriarchatowi Moskiewskiemu straty wizerunkowe na arenie 
międzynarodowej, zwłaszcza w kontekście wydarzeń na wschodzie Ukrainy (Chawryło, 2015, s. 40).

W kolejnych latach, władze DRL i ŁRL, ograniczając swobody religijne, zaczęły szerzej stosować instrumenty prawne, wzorowane na rozwiązaniach przyjętych w Rosji. Pomimo, że w konstytucjach tych republik oraz ustawach o wolności wyznania i związkach wyznaniowych, obecne są zapisy potwierdzające prawo każdego człowieka do wolności religijnej, to jednak w odniesieniu do KE, nie są w pełni stosowane. Narzędzia prawne mają zatem ograniczyć rozwój KE lub doprowadzić do ich wyparcia z DRL i ŁRL. Nie dziwi zatem, że ostrze represji o charakterze administracyjnym wymierzone zostało głównie w stronę liderów tych wspólnot.

Represje wymierzone w KE w DRL i ŁRL w znacznym stopniu ograniczyły ich potencjał misyjny, zasoby materialne oraz kapitał ludzki. Nie doprowadziły jednak do ich całkowitego wyeliminowania z tych obszarów, zerwania międzynarodowych powiązań z instytucjami chrześcijańskimi oraz z wierzącymi w innych krajach, choć niewątpliwie je skomplikowały, przyczyniając się do zmiany formy tych kontaktów. Prześladowania, którym zostali poddani wierni oraz duchowni, sprawiły, że niektórzy z nich wraz z rodzinami przesiedlili się w inne rejony Ukrainy lub wyemigrowali, np. do Polski.

KE stopniowo zaczęły adaptować się do zmienionej rzeczywistości, której wiele aspektów jest zbieżnych $\mathrm{z}$ realiami, w jakich część $\mathrm{z}$ nich funkcjonowała w czasach Związku Radzieckiego. To sprawia, że wyzwania, przed którymi stanęły, nie są całkowicie nowe. W wielu parafiach nadal są czynni duchowni, którzy byli represjonowani przez komunistów. Dysponują zatem istotnym zasobem doświadczenia i wiedzy, jak radzić sobie w sytuacji represyjnych działań ze strony władz.

Zaistniałe okoliczności w DRL i ŁRL wpłynęły na kształt oraz intensywność dyskusji wśród ewangelikalnych protestantów, a także w wywodzącej się z tego środowiska emigracji, nad sprawami dotyczącymi zaangażowania politycznego chrześcijan, ich rozumienia patriotyzmu oraz czynnego udziału wiernych i duchowieństwa w walkach. W tych kwestiach - podkreślmy zarysowały się pewne linie podziałów ${ }^{4}$.

${ }^{4}$ Powyższy wątek pojawiał się na tyle incydentalnie, że jego opracowanie wymagałoby sporządzenia odrębnej, pogłębionej kwerendy. 
Trudno prognozować, jak w najbliższych latach w DRL i ŁRL będą układały się relacje pomiędzy ewangelikalnymi protestantami a wyznawcami prawosławia, sympatyzującymi z RKP. Wsparcie, jakiego udzielili niektórzy prawosławni duchowni separatystom, a w tym przypadki ich udział w represjach wobec wiernych i duszpasterzy KE, są czynnikami niewątpliwie utrudniającymi proces zbliżenia pomiędzy tymi środowiskami. Pamiętać należy jednak, że w nauczaniu kościelnym ewangelikalni protestanci akcentują konieczność bezwarunkowego przebaczenia prześladowcy. Stanowi ono moralny obowiązek chrześcijanina, bez którego nie jest możliwe uzyskanie przebaczenia Bożego (Андросов, 2017). Dodajmy, że Ogólnoukraińska Rada Kościołów i Organizacji Religijnych w 2017 r. podkreśliła, że „przebaczenie jest ważnym elementem działań pokojowych na drodze do deeskalacji i rozwiązywania konfliktów” (ВРЦіРО, 2017).

\section{DR HAB. TOMASZ R. DĘBOWSKI, PROF. UWR}

Instytut Studiów Międzynarodowych

Wydział Nauk Społecznych

Uniwersytet Wrocławski

ul. Koszarowa 3, 51-149 Wrocław

tomasz.debowski@uwr.edu.pl

\section{Bibliografia}

Adams, G.J. (2017, 7 grudnia). Christian Widow From Ukraine Talks About Murdered Husband, War (Exclusive). Pobrane z: https://onewestand.org/stories/christian-widow-from-ukraine-talks-about-murdered-husband-war-exclusive.html.

Андросов, Г. (2017, 20 grudnia). Образа - гріх, який веде до смерті. Pobrane z: http:// www.chve.org.ua/obraza-hrikh-iakyi-vede-do-smerti.ukraine-talks-about-murdered-husband-war-exclusive.html.

Baluk, W., Doroszko, M. (2017). Wojna hybrydowa Rosji przeciwko Ukrainie w latach 2014-2016. Lublin: Wydawnictwo Uniwersytetu Marii Curie-Skłodowskiej.

Banasik, M. (2016). Planowanie strategiczne bezpieczeństwa narodowego. Wybrane problemy. Toruń: Wydawnictwo Adam Marszałek.

Besançon, A. (2015). Święta Ruś. Warszawa: Teologia Polityczna.

Булатчик, В. (2019, 13 czerwca). Религиозная несвобода. Чем отличается жизнь верующих в «ДНР» и «ЛНР». Pobrane $\mathrm{z}$ : https://www.ostro.org/general/politics/ articles/570466. 
Center for Civil Liberties (CCL) (2015, kwiecień). When God Becomes the Weapon. Persecution based on religious beliefs in the armed conflict in Eastern Ukraine. Pobrane z: http://ccl.org.ua/wp-content/uploads/2013/07/When-God-Becomes-The-Weapon_6May2015_closed-for-editing.pdf.

Center for Civil Liberties and International Partnership for Human Right (CCL/IPHR) (2015, 6 maja). When God Becomes The Weapon. Pobrane z: https://iphronline.org/ wp-content/uploads/2015/07/when_god_becomes_the_weapon_may2015.pdf.

Chawryło, K. (2015). Sojusz ołtarza z tronem. Rosyjski Kościół Prawosławny a władza w Rosji. Prace OSW, 54, s. 1-42.

Corley, F. (2018, 12 listopada). DONBAS: Donetsk: Places of worship seized, sealed. Pobrane $\mathrm{z}$ : http://www.forum18.org/archive.php?article_id=2422.

Czajko, E. (2014). Nasz wiara. Próba dogmatyki zielonoświątkowej. Warszawa: Kościół Zielonoświątkowy Zbór Stołeczny w Warszawie.

Центром Разумкова (CR). (2018). Особливості релігійного і иерковно-релігійного самовизначення українських громадян: тендениії 2010-2018рр. (інформаційні матеріали). Pobrane z: http://razumkov.org.ua/uploads/article/2018_Religiya.pdf.

Центром Разумкова (CR). (2020). Конфесійна та церковна належність громадян України (січень 2020р. соціологія). Pobrane z: https://razumkov. org.ua/napriamky/sotsiologichni-doslidzhennia/konfesiina-ta-tserkovna -nalezhnist-gromadian-ukrainy-sichen-2020r.

Dvorkin, A. (2005). Główne cechy sekt totalitarnych. Elpis, 7, s. 99-108.

Euromaidan Press (EP). (2016, 25 marca). Protestants - one of the most pro-Ukrainian groups in the Donbas. Pobrane z: http://euromaidanpress.com/2016/03/25/ protestants-one-of-the-most-pro-ukrainian-groups-in-the-donbas.

Фионик, Д. (2014, 28 września). Восхождение. Кто убил четырёх христиан в осаждённом Славянске. Pobrane z: https://focus.ua/ukraine/314132.

Głos Prześladowanych Chrześcijan (GPCh). (2018, 31 sierpnia). UKRAINA: Ataki na chrześcijan $w$ Ługańsku. Pobrane z: https://www.gpch.pl/bi/243-ukraina /1688-ukraina-ataki-na-chrzescijan-w-lugansku.

Głos Prześladowanych Chrześcijan (GPCh). (2019, 13 kwietnia). Ukraina: Antychrześcijańskie restrykcje $w$ obwodach ługańskim i donieckim. Pobrane z: https://www. gpch.pl/bi/243-ukraina/1756-ukraina-wzmozone-restrykcje-na-obszarach-autonomicznych.

Główny Urząd Statystyczny (GUS). (2020, 28 lutego). Wyznania religijne w Polsce w latach 2015-2018. Pobrane $\mathrm{z}$ : https://stat.gov.pl/download/gfx/portalinformacyjny/pl/ defaultaktualnosci/5500/5/2/1/wyznania_religijne_w_polsce_2015-2018.pdf.

Institute for Religious Freedom (IRF). (2018, 24 października). Religious Freedom at Gunpoint: Russian Terror in the Occupied Territories of Eastern Ukraine. Pobrane z: https://irf.in.ua/files/publications/2018.10.24-IRF-Report-ENG.pdf.

Gowryś, P. (2014, 28 lutego). Kaznodzieja i pisarz z ciemna karta $w$ WikiLeaks. Kim jest Oteksandr Turczynow? Pobrane z: https://polskatimes.pl/kaznodzieja-i-pisarz-z-ciemna-karta-w-wikileaks-kim-jest-oleksandr-turczynow-zdjecia/ ar/3349009.

Havryliuk, A. et. al. (2014, 22 lipca). Statement MENT of Heads of Evangelical Protestant Churches of Ukraine on religious persecution in the Donetsk and Luhansk Oblasts. 
Pobrane z: http://euromaidanpress.com/2014/07/22/statement-of-heads-of-evangelical-protestant-churches-of-ukraine-on-religious-persecution-in-the-donetsk-and-luhansk-oblasts.

Kałużny, T. (2014). Andrieja Kurajewa krytyka ekumenizmu. Sympozjum, nr 2(27), s. 79-92.

Karpitsky, N. (2015). Persecution of Christians in the Donbas (Eastern Ukraine, 2014). Kijów: Mission Eurasia.

Kharkiv Human Rights Protection Group (KHRPG). (2017, 16 lipca). Russian lies about Slovyansk church members murdered by militants. Pobrane z: http://khpg.org/en/ index.php?id=1405482662.

Ławreszuk, M. (2009). Prawosławie wobec tendencji nacjonalistycznych i etnofiletystycznych. Warszawa: Wydawnictwo Naukowe Semper.

Максимов, Г. (2015, 17 października). Правоставие и протестантизм: в чем разница. Pobrane z: https://azbyka.ru/otechnik/Georgij_Maksimov/pravoslavie -i-protestantizm-v-chem-raznitsa.

Министерства Государственной Безопасности Донецкой Народной Республики (MВРDRL). (2015, 2 lipca). СМИ о МГБ ДНР. Pobrane $\mathrm{z}$ : https://mgbdnr.ru/articles. php?id=20150702_00\&img_num $=1$.

Modnicka, N. (2013). Specyfika polskiego ewangelikalizmu. W: W. Kowalewski, S. Smolarz, S. Torbus (red.). Ewangelikalizm polski wobec wyzwań wspótczesności (39-49). Wrocław: CREDO.

Народный Совет Донецкой Народной Республики (RDRL). (2014, 14 maja). Конституиия Донецкой Народной Республики. Pobrane z: https://dnrsovet.su/ konstitutsiya.

Народный Совет Донецкой Народной Республики (RDRL). (2019, 18 października). Закон ДНР «О свободе вероисповедания и религиозных объединениях». Pobrane z: https://dnrsovet.su/zakonodatelnaya-deyatelnost/prinyatye/zakony/zakon-donetskoj-narodnoj-respubliki-o-svobode-veroispovedaniya-i-religioznyh-obedineniyah. Народный Совет Луганской Народной Республики (RŁRL). (2014, 18 maja). Закон “Конституция Луганской Народной Республики". Pobrane z: https://www.nslnr. su/zakonodatelstvo/konstitutsiya.

Народный Совет Луганской Народной Республики (RŁRL). (2018, 7 lutego).

Закон «О свободе совести и о религиозных объединениях». Pobrane z: https://www. nslnr.su/zakonodatelstvo/normativno-pravovaya-baza/zakonodatelstvo/5741.

Organization for Security and Co-operation in Europe (OSCE). (2016, 26 sierpnia). Conflict-related Displacement in Ukraine: Increased Vulnerabilities of Affected Populations and Triggers of Tension within Communitiess. Pobrane z: https://www.osce. org/ukraine-smm/261176?download=true.

Pacek, B. (2018). Wojna hybrydowa na Ukrainie. Warszawa: Oficyna Wydawnicza RYTM. Pawlak, C. (2017). Konflikt na Wschodzie Ukrainy i aneksja Krymu - standardowym przykładem działań hybrydowych. Rocznik Bezpieczeństwa Międzynarodowego, 11(1), s. 268-287.

Peterson, S. (2014, 12 sierpnia). A Ukrainian murder mystery ensnares a church in former rebel stronghold. Pobrane z: https://www.csmonitor.com/World/Europe/2014/0812/A-Ukrainian-murder-mystery-ensnares-a-church-in-former-rebel-stronghold. 
Portal Ekumenizm.pl (PE). (2014, 8 września). Prześladowania chrześcijan ewangelikalnych na wschodzie Ukrainy. Pobrane z: https://www.ekumenizm.pl/koscioly/ protestanckie/przesladowania-chrzescijan-ewangelikalnych-na-wschodzie-ukrainy.

Релігійно-інформаційна служба України (RISU). (2017, 8 września). Баптистському пастору заборонили в їзд у „ДНР”. Pobrane z: https://risu.org.ua/ua/index/ all_news/community/freedom_of_conscience/68193.

Релігійно-інформаційна служба України (RISU). (2018a, 31 stycznia). Поліція встановила вбивць п'ятидесятників у Слов'янську. Pobrane z: https://risu.org. ua/ua/index/all_news/community/terrorism/69924.

Релігійно-інформаційна служба України (RISU). (2018b, 7 kwietnia). ОБСЄ підтвердила пограбування бойовиками „ЛНР” молитовного дому євангельських християн-баптистів у Кадївиі. Pobrane z: https://risu.org.ua/ua/index/all_news/ community/terrorism/70745.

Релігійно-інформаційна служба України (RISU). (2018c, 27 września). Бойовики “ЛНР” вчинили погром у домі молитви баптистів у Брянці. Pobrane z: https:// risu.org.ua/ua/index/all_news/community/terrorism/72809.

Rogozińska, A. (2019). Non-military dimension of the hybrid war in Ukraine. Srodkowoeuropejskie Studia Polityczne, 2, s. 173-194.

Rosyjski Kościół Prawosławny (RKP). (2008, 9 czerwca). Основы социальной кониепции Русской Православной Церкви. Pobrane z: http://www.patriarchia.ru/ $\mathrm{db} / \mathrm{text} / 419128 . \mathrm{html}$.

Rosyjski Kościół Prawosławny (RKP). (2009, 3 listopada). Выступление Святейшего Патриарха Кирилла на торжественном открытии III Ассамблеи Русского мира. Pobrane z: http://www.patriarchia.ru/db/text/928446.html.

Shterin, M.S., Richardson, J.T. (2002). The Yakunin vs. Dvorkin Trial and the Emerging Religious Pluralism in Russia, Occasional Papers on Religion in Eastern Europe, 22, s. $1-22$.

Sobczak, J. (2018). Struktura organizacyjna Cerkwi prawosławnej w państwach Azji Środkowej. Nowa Polityka Wschodnia, 4(19), s. 7-38.

Sobczak, J., Gołda-Sobczak, M. (2012). Wolność sumienia i wyznania jako prawo człowieka, Annales Universitatis Mariae Curie-Skłodowska. Sectio K, Politologia, 19(1), s. 27-65.

Studenna-Skrukwa, M. (2014). Ukraiński Donbas. Oblicza tożsamości regionalnej. Poznań: Wydawnictwo Nauka i Innowacje.

Surdyk, K. (2017). Konflikt ukraiński w rozgrywkach geopolitycznych. Warszawa: Wydawnictwo Difin.

Шаповал, Е. (2016, 23 marca). Протестанты из Донбасса. Протестанты оказались одной из наиболее патриотичных сочиальных групп на охваченном войной востоке страны. Pobrane z: https://nv.ua/publications/v-donbasse-protestanty-okazalis-odnoj-iz-naibolee-patriotichnyh-sotsialnyh-grupp-104809.html.

Szczerba, W. (2013). Reformacyjne korzenie ewangelikalizmu. W: W. Kowalewski, S. Smolarz, S. Torbus (red.), Ewangelikalizm polski wobec wyzwań wspótczesności (13-26). Wrocław: CREDO. 
United States Commission on International Religious Freedom (USCIRF). (2018). 2018 Annual Raport. Pobrane z: https://www.uscirf.gov/sites/default/files/2018USCIRFAR.pdf.

United States Commission on International Religious Freedom (USCIRF). (2019, 24 kwietnia). USCIRF 2019 Annual Report. Pobrane z: https://www.uscirf.gov/sites/ default/files/2019USCIRFAnnualReport.pdf.

Vovk, D. (2020, 23 lipca). Religion and Forced Displacement in Ukraine. Pobrane z: https:// fpc.org.uk/religion-and-forced-displacement-in-ukraine.

Васин, М. (2014a, 2 sierpnia). Современные христиане-мученики. Pobrane z: https:// mvasin.org.ua/2014/07/880.

Васин, М. (2014b, 31 grudnia). "Религиозная” война на Донбассе. Pobrane z: https:// mvasin.org.ua/2014/11/955.

Васин, М. (2015, 13 stycznia). Підсумки 2014 року. Донбас і Крим: нові виклики для релігійної свободи. Pobrane z: https://old.irs.in.ua/index.php?option=com_ content\&view=article\&id=1496:1\&catid=37:art\&Itemid=64.

Всеукраїнська Рада Церков і релігійних організацій (ВРЦіРО). (2017, 10 grudnia). Стратегія участі Церков і релігійних організащій у миробудуванні «Україна - наш спільний дім». Pobrane z: https://www.vrciro.org.ua/ua/documents/ uccro-peacebuilding-strategy-ukraine.

Zenderowski, R. (2014). Religia i konflikty zbrojne. W: P. Burgoński, M. Giercz (red.). Religia i polityka. Zarys problematyki (600-627). Warszawa: Dom Wydawniczy Elipsa.

Zieliński, T.J. (1995). Purytanizm. Zarys dziejów ideologii i obyczajów anglosaskiego ruchu reformacyjnego. Rocznik Teologiczny, 2, s. 219-283.

Zoria, Y. (2018, 23 listopada). With Donbas occupation, Russia brought religious persecution alien to Ukraine: report. Pobrane z: http://euromaidanpress.com/2018/11/23/ with-donbas-occupation-russia-brought-religious-persecution-alien-to-ukraine-report. 